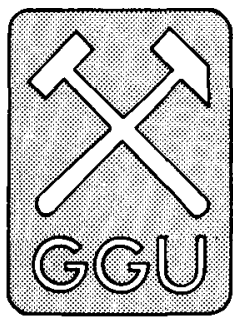

\title{
Evaluation of hydropower potential for possible future industrial use, Nuuk area, West Greenland
}

\author{
Henrik Højmark Thomsen, Roger J. Braithwaite, \\ Anker Weidick and Ole B. Olesen
}

The potential of Greenland hydropower came into focus following the energy crisis in 1973 and the subsequent demand for exploitation of Greenland's own energy resources. Investigations have been made since the mid-1970s on the feasibility of hydropower in Greenland. At first, emphasis was put upon large, or regional, basins that could supply new energy-intensive industries (GTO, 1975). During the 1980s, the emphasis changed to the so-called 'town basins' where hydropower would be developed to supplement the existing energy in selected Greenland towns. The first hydropower plant is under construction at the Kangerluarsunnguaq/Buksefjorden basin south-east of Nuuk, the capital of Greenland, to supply Nuuk with energy (Fig. 1). This hydropower plant is planned to come into operation in autumn 1993.

A recent report from Nukissiorfiit (Greenland Power Board) has updated the hydropower potential of Greenland (Nukissiorfiit, 1992). The report describes two types of hydropower plants: (1) small plants with a potential of less than $250 \mathrm{GWh}$ per year intended to supply nearby towns with energy; and (2) large plants with a potential greater than $250 \mathrm{GWh}$ per year intended to supply energy to nearby towns and energy intensive industries, or to energy-storage systems (production and storage of hydrogen are being investigated as a possibility).

The largest hydropower potential in Greenland is found in basins receiving meltwater from the Greenland ice sheet. In connection with a recent updating of hydropower potential, the Geological Survey of Greenland (GGU) has evaluated the runoff conditions from two basins in the Nuuk area, both connected to sectors of the Greenland ice sheet. One of these basins is the $S \varnothing$ 710/Isortuarsuup Tasia basin which is interesting as a possible expansion of the Kangerluarsunnguaq/Buksefjorden basin (Fig. 1). An expansion would involve transfer of water from an ice-dammed lake (Sø 710) which, under natural conditions, drains by periodical tapping to the Isortuarsuup Tasia basin south of Kangerluarsunnguaq/Buksefjorden. The second basin is the Imarsuup Isua basin which is estimated to have one of the largest hydropower potentials in Greenland (Nukissiorfiit, 1992). The present work by GGU comprises an evaluation of runoff and glaciological conditions based on the existing sparse data, to a large extent the results and experience from GGU's long-term glaciological research programme.

\section{Glaciological research related to hydropower planning}

GGU has been involved in glaciological investigations for planning hydropower in Greenland since the mid-1970s. The work is primarily research related to the exploitation of meltwater from the Greenland ice sheet (Weidick \& Thomsen, 1986; Weidick, 1990). It includes mass balance and climate studies (Braithwaite \& Olesen, 1985, 1989, 1990; Olesen \& Braithwaite, 1989), studies of surface and subglacial drainage for delineation of drainage basins (Thomsen, 1986; Thomsen \& Braithwaite, 1987; Thomsen et al., 1989; Thomsen \& Olesen, 1991) and development of models for runoff simulations (Braithwaite, 1980; Braithwaite \& Thomsen, 1989). Furthermore, tapping of ice-dammed lakes has been studied (Clement, 1984; Braithwaite \& Thomsen, 1984) and information about glacier fluctuations has been collected (Weidick, 1991) in order to evaluate possible glacier hazards and the consequences for hydropower plants, e.g. damage to technical installations due to advancing ice margins or changes of proglacial draining caused by change in a glacier's thickness and extent.

\section{Evaluation of runoff and glaciological conditions in the Nuuk area}

By far the largest part of the runoff from the two basins, Imarsuup Isua and $S \emptyset 710$, is meltwater from the Greenland ice sheet. However, no ablation measurements have been made in the two basins and only scattered runoff data exist.

Runoff from the two basins has been calculated from 


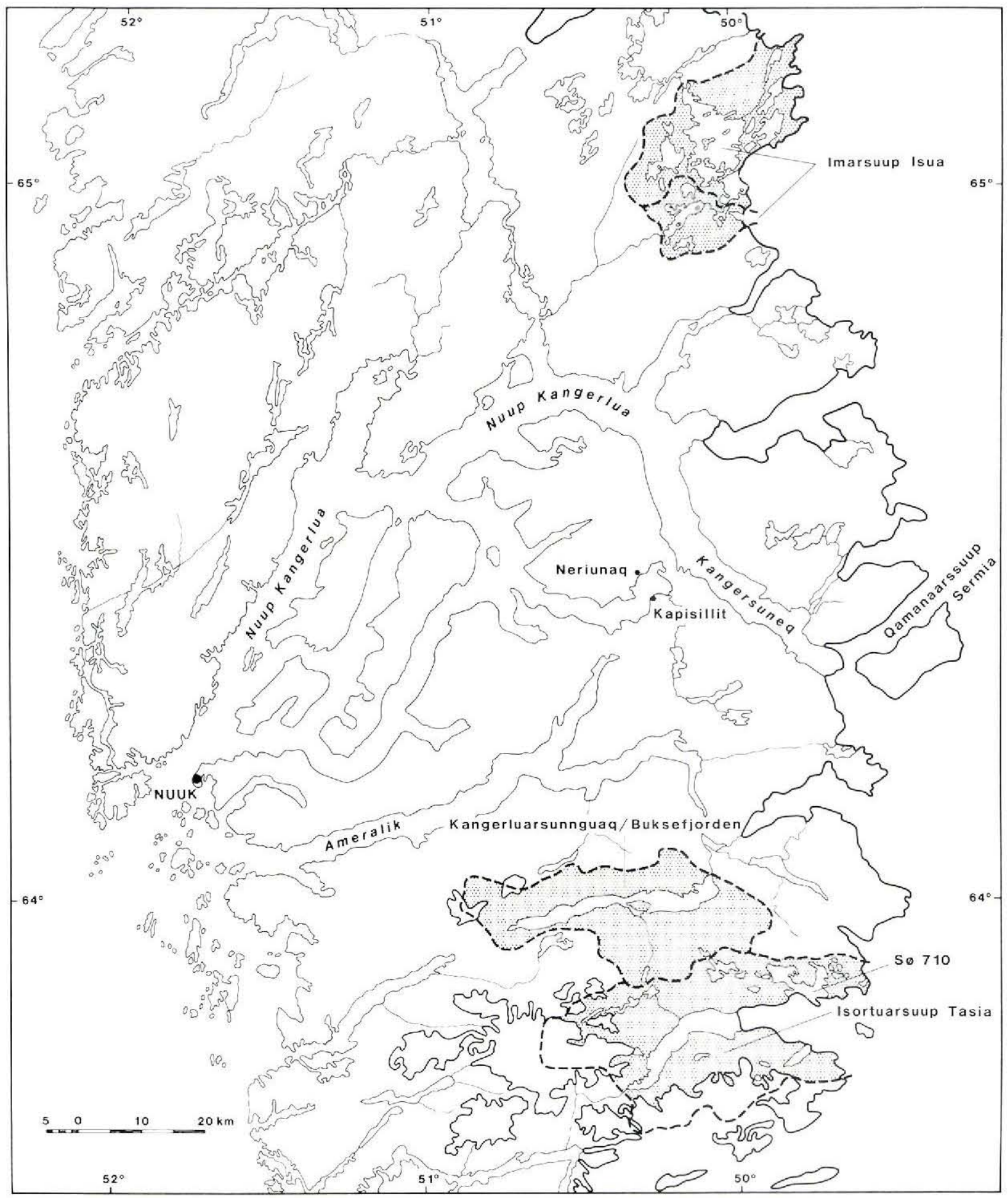

Fig. 1. Map of the Nuuk area showing hydrological basins mentioned in text. 
Fig. 2. Simulated runoff for Imarsuup Isua, West Greenland, for the period 19611990. Maximum and minimum calculations reflect different estimates of the drainage basin delineation on the ice sheet.
Imarsuup Isua

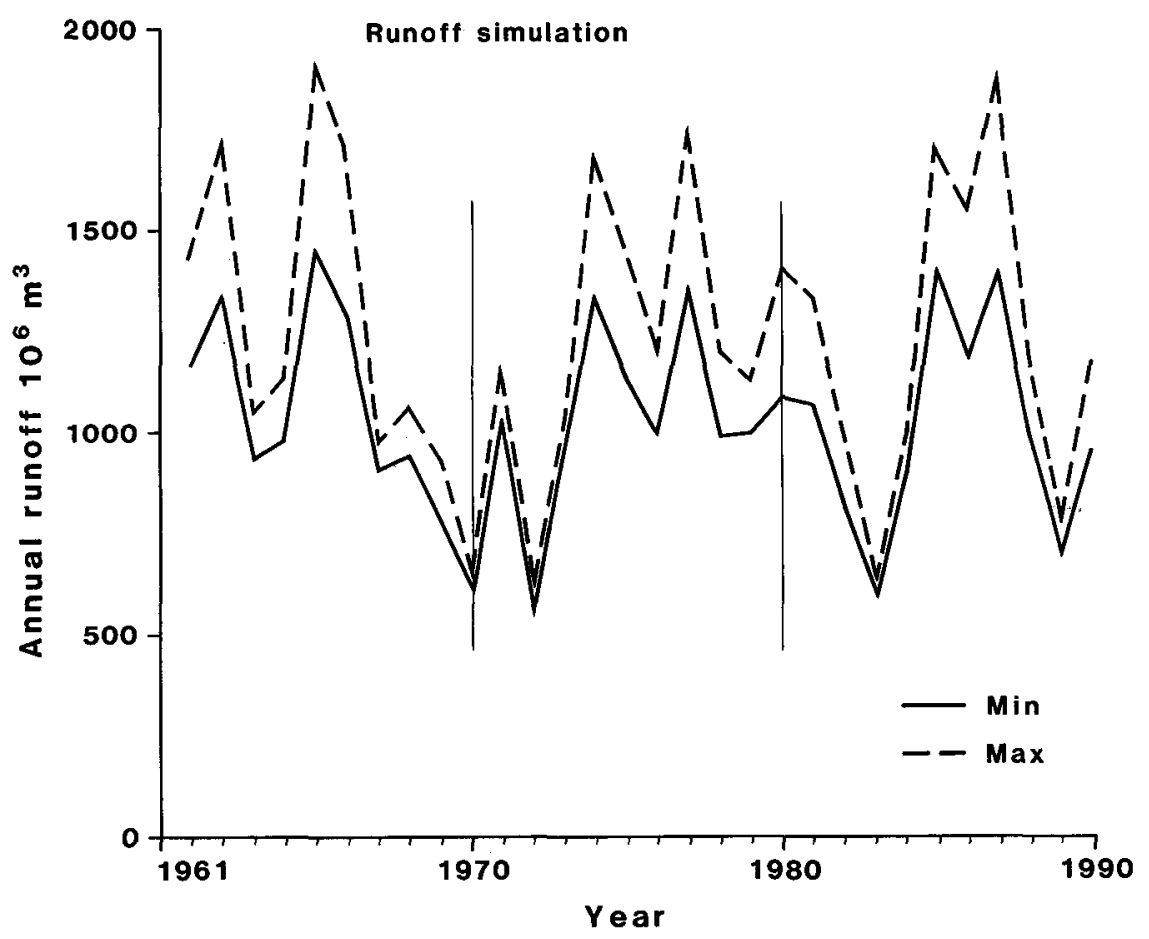

climate data collected in Nuuk by the Danish Meteorological Institute using models developed through GGU's long-term glaciological research programme (Braithwaite, 1980; Braithwaite \& Thomsen, 1989; Braithwaite et al., 1992). Various parameters for calculating the ice ablation have been derived from ice and climate studies made at Qamanaarsuup Sermia (Braithwaite \& Olesen, 1985, 1989), an outlet glacier from the Greenland ice sheet in the Nuuk area (Fig. 1). Drainage basins on the ice sheet were delineated using low sunangle Landsat satellite images, a method developed and applied by GGU during earlier hydropower investigations in Greenland (Thomsen, 1986; Thomsen \& Braithwaite, 1987). This method is based on assumptions of how structures seen on the ice surface reflect sub-surface conditions and thus influence the meltwater drainage pattern. Due to uncertainties in the drainage basin delineation using this method, both maximum and minimum drainage basins are used in the runoff calculations. An example of the runoff calculations for the Imarsuup Isua basin is shown in Fig. 2. The calculated series show significant differences in the calculated runoff mainly due to the uncertainties in the drainage basin delineation.

Tapping events for the ice-dammed lake, $\$ \varnothing 710$, have been studied using aerial photographs and Landsat satellite images, and the volume of the lake has been estimated from existing maps. In this connection different possibilities for transfer of water from the lake to the neighbouring basin Kangerluarsunnguaq/Buksefjorden have been evaluated.

These results form a basis for ongoing planning and reevaluation of the Greenland hydropower potential by Greenland Power Board (Nukissiorfiit, 1992).

\section{References}

Braithwaite, R. J. 1980: Regional modelling of ablation in West Greenland. Rapp. Grønlands geol. Unders. 98, 20 pp. Braithwaite, R. J. \& Olesen, O. B. 1985: Ice ablation in West Greenland in relation to air temperature and global radiation. Z. Gletscherk. Glazialgeol. 20(1984), 155-168.

Braithwaite, R. J. \& Olesen, O. B. 1989: Calculation of glacier ablation from air temperature, West Greenland. In Oerlemans, J. (ed.) Glacier fluctuations and climatic change, 219233. Dordrecht: Kluwer Academic Publishers.

Braithwaite, R. J. \& Olesen, O. B. 1990: A simple energy balance model to calculate ice ablation at the margin of the Greenland ice sheet. J. Glaciol. 36(123), 222-228.

Braithwaite, R. J. \& Thomsen, H. H. 1984: Runoff conditions at Kuussuup Tasia, Christianshåb, estimated by modelling. Grønlands geol. Unders. Gletscher-hydrol. Meddr 84/2, 24 pp.

Braithwaite, R. J. \& Thomsen, H. H. 1989: Simulation of run-off from the Greenland ice sheet for planning hydroelec- 
tric power, Jakobshavn/llulissat, West Greenland. Ann. Glaciol. 13, 12-15.

Braithwaite, R. J., Olesen, O. B. \& Thomsen, H. H. 1992: Calculated variations of annual ice ablation at the margin of the Greenland ice sheet, West Greenland, 1961-90. J. Glaciol. 38(129), 266-272.

Clement, P. 1984: The drainage of a marginal ice-dammed lake at Nordbogletscher, Johan Dahl Land, South Greenland. Arctic Alp. Res. 16(2), 209-216.

GTO, 1975: Lokalisering af vandkraftressourcer på Grønlands vestkyst, $58 \mathrm{pp}$. Copenhagen: Grønlands Tekniske Organisation (unpublished report).

Nukissiorfiit, 1992: Vandkraftmuligheder og prioritering af vandkraftudbygningen i Grønland, $53 \mathrm{pp}$. Copenhagen: $\mathrm{Nu}$ kissiorfiit, Grønlands Energiforsyning (unpublished report).

Olesen, O. B. \& Braithwaite, R. J. 1989: Field stations for glacier-climate research, West Greenland. In Oerlemans, J. (ed.) Glacier fluctuations and climatic change, 207-218. Dordrecht: Kluwer Academic Publishers.

Thomsen, H. H. 1986: Photogrammetric and satellite mapping of the margin of the Inland Ice, West Greenland. Ann. Glaciol. 8, 164-167.
Thomsen, H. H. \& Braithwaite, R. J. 1987: Use of remotesensing data in modelling run-off from the Greenland ice sheet. Ann. Glaciol. 9, 215-217.

Thomsen, H. H. \& Olesen, O. B. 1991: Hydraulics and hydrology on the Inland Ice. Rapp. Gronlands geol. Unders. 152, 36-38.

Thomsen, H. H., Thorning, L. \& Olesen, O. B. 1989: Applied glacier research for planning hydro-electric power, Ilulissat/ Jakobshavn, West Greenland. Ann. Glaciol. 13, 257-261.

Weidick, A. 1990: Investigating Greenland's glaciers. Rapp. Grønlands geol. Unders. 148, 46-51.

Weidick, A. 1991: Present-day expansion of the southern part of the Inland Ice. Rapp. Grønlands geol. Unders. 152, 73-79.

Weidick, A. \& Thomsen, H. H. 1986: A decade of glacier investigations for utilisation of Greenland hydropower. Rapp. Grønlands geol. Unders. 128, 157-169.

H. H. T., R. J. B., A. W. \& O. B. O., Geological Survey of Greenland, Copenhagen.

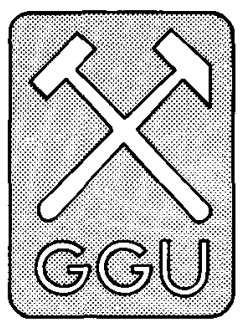

\title{
Measurements of firn density in the lower accumulation area of the Greenland ice sheet: EPOCH 1992
}

\author{
Roger J. Braithwaite and Martin Laternser
}

Groups from several countries are studying Greenland glaciers in connection with the 'greenhouse effect' (Braithwaite et al., 1992a). In particular, GGU is the Danish partner in a 10-nation two-year project (March 1991 to February 1993) on causes and effects of sea level changes which is funded by the European Community through the European Programme on Climatology and Natural Hazards (EPOCH). As its contribution to EP$\mathrm{OCH}, \mathrm{GGU}$ is studying the effects of meltwater refreezing in the lower accumulation area of the Greenland ice sheet which may reduce, or at least delay, the expected sea level rise under warmer climate.

Work done under EPOCH in 1991 was described by Braithwaite et al. (1992b) while the present note describes the most important results of the 1992 field work.

\section{Background}

The field area is above Paakitsoq (formerly spelt Pâkitsoq), about $80-120 \mathrm{~km}$ east of Ilulissat/Jakobshavn (Fig. 1), where GGU has measured mass-balance in the ablation area since 1982 (Thomsen et al., 1989). A line of accumulation stakes was established in 1990 and 1991 from the upper part of the ablation area to well within the accumulation area (see sketch map in Braithwaite $e t$ $a l ., 1992 b)$. Three-dimensional stake positions were measured at various times with a hand-held Global Positioning System (GPS), and elevations of stakes and surface features are shown in Table 1 with an estimated accuracy of $\pm 35 \mathrm{~m}$.

Observations in 1991 strongly suggested that firn densification, and especially the change of firn to ice, is a 